\title{
Characterization of the virulence, growth temperature and antibiotic resistance of the Campylobacter jejuni IAL 2383 strain isolated from humans
}

\author{
B.B. Fonseca ${ }^{1}$, D.A. Rossi ${ }^{2}$, C.A. $\mathrm{Maia}^{2}$, P.C. Nalevaiko ${ }^{2}$, R.T. Melo ${ }^{2}$, \\ L.P. Cuccato ${ }^{1}$, M.E. Beletti ${ }^{3}$ \\ ${ }^{1}$ Faculdade de Medicina Veterinária, Universidade de Uberaba, Uberaba, MG, Brazil. \\ ${ }^{2}$ Laboratório de Biotecnologia Animal Aplicada, Universidade Federal de Uberlândia, Uberlândia, MG, Brazil. \\ ${ }^{3}$ Centro de Microscopia Eletrônica, Universidade Federal de Uberlândia, Uberlândia, MG, Brazil. \\ Submitted: July 10, 2012; Approved: April 1, 2013.
}

\begin{abstract}
The objective of this study was to characterize the $C$. jejuni IAL2383 strain isolated from humans in Brazil. Transcripts for the $r a c R$, dnaJ and ciaB genes were found and flaA, plda and $c a d F$ genes were present in the genome and bacteria was sensitive to most of the important antimicrobials used to treat humans. C. jejuni IAL2383 is a good experimental model to analyze the interactions with cells.
\end{abstract}

Key words: virulence, experimental model, thermotolerance, Campylobacter jejuni.

\section{Introduction}

The diversity of Campylobacter jejuni reflects this bacterium's ability to colonize and cause disease. Variation in the virulence factors of different strains has been observed in in vitro and in vivo models, demonstrating different strategies and consequent risks. An understanding of the molecular basis of the virulence patterns of the strains associated with disease and knowledge of the genetic diversity among strains are of paramount importance in disease control (Ahmed et al., 2002).

The C. jejuni-host cell interaction mechanisms are not well understood, and there is great disagreement among researchers. Some of the conflicting results may be explained by differences between strains, which have been reported by some authors (Deun et al., 2008; Li et al., 2008). The $C$. jejuni IAL2383 strain was isolated from humans with clinical symptoms in Brazil and is maintained by the Instituto Adolfo Lutz strains. This strain appears to be ideal for understanding the pathogen-host interactions because this strain causes symptoms in humans. However, the virulence factors, degree of thermotolerance and resistance to antibiotics of this strain have not been analyzed. The aim of this study was to characterize the IAL2383 strain based on the presence of certain genes, the expression of transcripts for the major $C$. jejuni virulence factors, the growth temperature and resistance to antibiotics.

\section{Materials and Methods}

This study used the C. jejuni strain IAL 2383, which was isolated from a human outbreak and is maintained at the Bank of the Instituto Adolfo Lutz, São Paulo (IAL). All experiments were performed with bacteria from the first expansion after receipt from the Bank.

The antibiotic resistance of the IAL2383 strain was analyzed by the Kirby-Bauer disk diffusion method (Bauer et al., 1966) using the protocol recommended by the National Committee for Clinical Laboratory Standards. The following antibiotics were tested: trimethoprim $(5 \mu \mathrm{g})$, cefoxitin $(30 \mathrm{mg})$ ceftiofur $(30 \mathrm{mg})$, neomycin $(30 \mathrm{mg})$, chloramphenicol (30 mg), trimethoprim-sulfamethoxazole $(23 \mathrm{mg})$, amoxicillin $(10 \mathrm{mg})$, tetracycline $(30 \mathrm{mg})$, gentamicin $(10 \mathrm{mg})$, nalidixic acid $(30 \mathrm{mg})$, norfloxacin $(10 \mathrm{mg})$, enrofloxacin $(5 \mathrm{mg})$, erythromycin $(15 \mathrm{mg})$, and sulfazotrim $(300 \mathrm{mg})$. The assays were performed in triplicate on Mueller Hinton agar (Difco) containing 5\% horse blood hemolysate. The plates were incubated at a temperature of $37{ }^{\circ} \mathrm{C}$ for $48 \mathrm{~h}$ in a microaerophilic atmosphere (Probac Brazil).

To determine the optimum temperature for the growth of $C$. jejuni IAL 2383. Nine serial dilutions were performed. Aliquots of $0.1 \mathrm{~mL}$ of the $10^{6}$ to $10^{9}$ dilutions were removed and placed on the surface of CCDA agar (Oxoid) and spread using a Drigalski spatula. Each dilution 
was streaked in triplicate on plates that were then incubated at temperatures of 37 and $41^{\circ} \mathrm{C}$ in parallel. After $30 \mathrm{~h}$ of incubation in a microaerophilic atmosphere, the bacteria were quantified.

Primers described in the literature were used to determine if strain IAL2383 harbors the virulence genes $c a d F$, pldA (Zheng et al., 2006) and flaA (Hänel at al., 2004). C. jejuni NCTC 11351 was used as a positive control strain. The extraction of DNA was performed described by Guo et al. (2000) and Borsoi et al. (2009) with modifications. The final amplification reaction was composed of $20 \mathrm{ng}$ of bacterial DNA and others reagent (Invitrogen) to PCR. The microtubes were placed in a thermocycler (Eppendorf) and subjected to annealing temperature at $45^{\circ} \mathrm{C}$. At the end of the reaction, the amplified products were subjected to electrophoresis and visualized with a UV transilluminator (L.PIX Loccus Biotechnology).

Assays were performed to verify that the virulence genes $c i a B$, dnaJ and $r a c R$ were expressed in $C$. jejuni IAL2383 (Li et al., 2008). To do this, we performed reverse transcriptase (RT- PCR) and then conventional PCR. We conducted a test with 3 types of bacteria: C. jejuni IAL2383; C.coli isolated from chicken (expression of virulence factors no know), and a virulent strain of $C$. jejuni NCTC 11351 (positive control). All strains were incubated at a temperature of $41{ }^{\circ} \mathrm{C}$. In addition, to determine the change in the levels of transcripts in the presence of eukaryotic cells, Caco-2 cells (derived from a human colon adenocarcinoma) infected with $2.0 \times 10^{7} \mathrm{CFU}$ C. jejuni IAL 2383 were used. RNA was extracted using the Trizol Reagent ${ }^{\circledR}$ method (Invitrogen). After RNA extraction, reverse transcription was used to synthesize the cDNA using RNase inhibitor (Invitrogen), MMLV-RT (Amersham Biosciences), MMLV-RT buffer (Amersham Biosciences), $200 \mathrm{mM}$ dNTPs and $126 \mathrm{pmol}$ of random hexamers as primers at $37^{\circ} \mathrm{C}$ for 1 hour. Control reactions were used to verify the presence of exogenous contaminants. The final volume of the amplification reaction included $3 \mu \mathrm{L}$ of the cDNA and PCR reagents (Invitrogen). The microtubes were placed in a thermocycler (Eppendorf) and submitted to annealing temperature $51^{\circ} \mathrm{C}$. At the end of the reaction, the amplified products were subjected to electrophoresis on agarose gels as performed for the presence of genes in the bacterial genome as oversized above.

\section{Results and Discussion}

Our results indicate that the C. jejuni IAL 2383 strain is susceptible to most antibiotics tested, the exceptions were trimethoprim $(5 \mu \mathrm{g})$ and cefoxitin $(30 \mathrm{mg})$. Many strains of $C$. jejuni exhibit multidrug resistance to antimicrobial agents (Jonker and Picard, 1999; Chen et al., 2011), and the resistance of pathogenic Enterobacteriaceae to fluoroquinolones and third-generation cephalosporins rep- resents a major problem because of the possibility of generating superbugs (Pignatari, 2011).

Regarding the various groups of antibiotics, the resistance of Campylobacter to macrolides, fluoroquinolones, beta-lactam, trimethoprim and sulphonamides has been high in several studies, while resistance to other antimicrobials agents including tetracycline, aminoglycoside and chloramphenicol is generally low (Aarestrup and Engberg, 2001; Yan et al., 2005). The sensitivity of this strain shows that it can be used as a negative control strain for resistance to most classes of antimicrobials or for the testing of the acquisition of resistance.

The bacterium grew better at $41^{\circ} \mathrm{C}$, and the number of colonies could be counted only after diluting by $10^{8}$ or more. At the temperature of $37^{\circ} \mathrm{C}$, the average growth was $8 \times 10^{7} \mathrm{cfu}(\mathrm{SD}=0.060)$, lower than the average of $2 \times 10^{8}$ $(\mathrm{SD}=0.242)$ at $41^{\circ} \mathrm{C}$.

C. jejuni IAL 2383 was found to harbor the virulence genes $c a d \mathrm{~F}$, plda and flaA (Figure 1). These genes, in addition to $c i a B$, are used to study the pathogenic mechanisms of $C$. jejuni (Hänel et al., 2004; Zheng et al., 2006). The RT-PCR results showed that the bacterium expressed transcripts for the $c i a B, d n a J$ and $r a c R$ proteins even in the absence of contact with eukaryotic cells (Figure 2).

Microorganisms with an optimal growth temperature near the body temperature of the birds, which varies between $40{ }^{\circ} \mathrm{C}$ and $42{ }^{\circ} \mathrm{C}$ (18), including the strain studied herein, have the greatest ability to survive in and colonize the bodies of animals. Coupled with the growth temperature, the presence of transcripts of the racR and $d n a J$ genes indicates that the strain used in this work can colonize the intestinal tracts of poultry. Therefore, this strain could be useful as a model to assess the pathogenesis of $C$. jejuni in these animals because $r a c R$ is a component of the racR and RACS (reduced Ability to colonize) regulation system and is involved in the ability of these bacteria to colonize the intestinal tracts of birds (Bras et al., 1999). The dnaJ gene encodes a heat shock protein that allows the bacteria to grow at temperatures greater than $40{ }^{\circ} \mathrm{C}$ (Konkel et al., 1998).

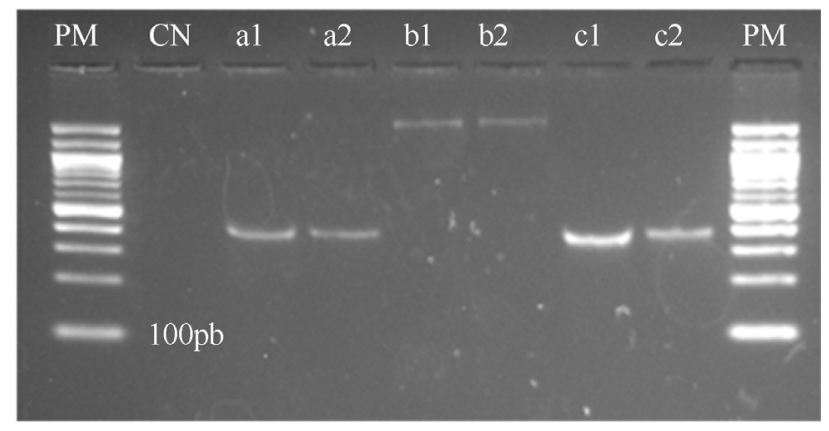

Figure 1 - PCR to presence of genes $c a d F$, flaA and plda to C. jejuni IAL 2383. $\mathrm{PM}=100$-bp molecular weight marker. $\mathrm{CN}$ : negative control, a.1: gene cadF C. jejuni NCTC 11351, a.2: gene cadF C. jejuni IAL 2383, b.1: gene flaA C. jejuni NCTC 11351, b.2: gene flaA C. jejuni IAL 2383, c.1: gene plda C. jejuni NCTC 11351, c.2: gene plda C. jejuni IAL 2383. 


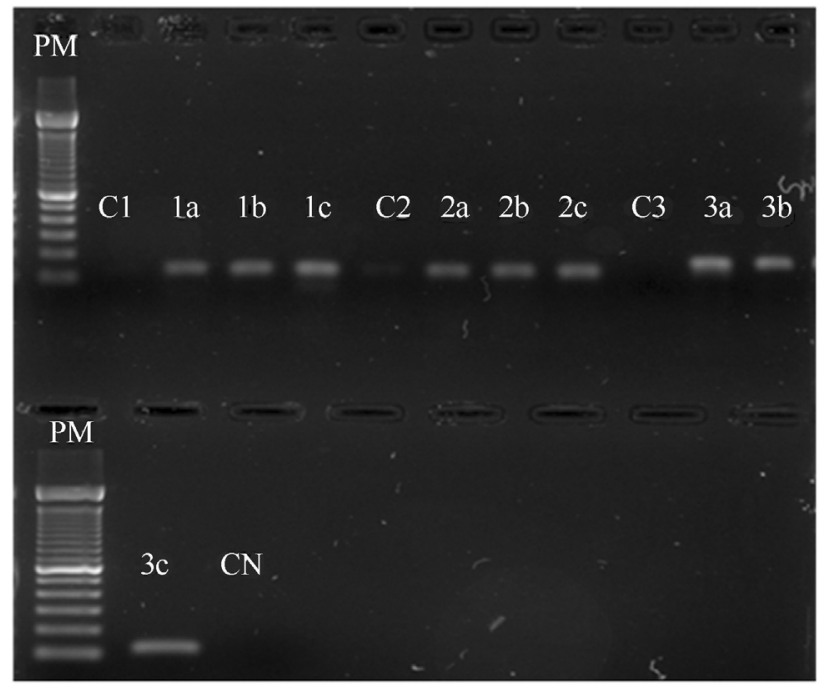

Figure 2 - RT-PCR to presence of transcripts genes $\operatorname{dnaJ}(1), \operatorname{racR}(2)$ $\operatorname{cia} B(3) . \mathrm{PM}=100$-bp molecular weight marker. $1($ dnaJ $) \mathrm{C} 1=$ C.coli chicken isolated $1 \mathrm{a}=C$. jejuni IAL $2383,1 \mathrm{~b}=\mathrm{Caco}-2$ cells with $C$. jejuni IAL2383, $1 \mathrm{c}=C$. jejuni NCTC 11351. $2($ racR $)$ C2 C.coli chicken isolated, $2 \mathrm{a}=C$. jejuni IAL 2383, $2 \mathrm{~b}=$ Caco-2 cells with $C$. jejuni IAL 2383, $2 \mathrm{c}=C$. jejuni $\mathrm{NCTC} 11351.3(\mathrm{ciaB}) \mathrm{C} 3=C$. coli chicken isolated, $3 \mathrm{a}=C$. jejuni IAL 2383, 3b = Caco-2 cells with $C$. jejuni IAL 2383, 3c $=C$. jejuni NCTC 11351, CN: negative control.

The presence of the $c i a B$ transcripts in this strain is important because the secretion of the corresponding protein is of great importance for the invasion of epithelial cells and the colonization of the intestines of birds (Konkel et al., 1999; Ziprin et al., 2001). In previous studies, we found that the strain causes early embryonic mortality in chicken embryos (Fonseca et al., 2011), changes the size of enterocytes in chicken embryos (Santos et al., 2011) and induces the production of inflammatory cytokines in ileum fragments of SPF (specific pathogen free) birds and the production of inflammatory cytokines and chemokines in Caco-2 cells by activating the innate immune system (data not shown). This strain also alters the size of ileum fragments in SPF birds and Caco-2 cells (data not shown).

The presence of these virulence genes reflects the adhesion, invasion and internalization abilities of strain IAL2383. The fla $\mathrm{A}$ gene is necessary for the adhesion to and invasion of epithelial cells. The $c a d F$ gene encodes a protein that interacts with fibronectin in the extracellular matrix of the host, thus participating in colonization (Monteville et al., 2003). The $p l d A$ gene is related to cell invasion and encodes a protein involved in the synthesis of an outer membrane phospholipase (Ziprin et al., 2001).

C. jejuni IAL2383 strain does not show resistance to the primary antibiotics used to treat humans and animals infected by enterobacteria. This strain harbors virulence genes and produces transcripts from the major virulence genes. Because of these characteristics, this strain is a useful model for the in vitro analysis of the acquisition of resis- tance to antibiotics and the pathogenicity in chickens and humans.

\section{References}

Arestrup F, Engberg J (2001) Antimicrobial resistence of thermophilic Campylobacter. Vet Re 32:311-321.

Ahmed IH, Manning G, Wassenaar TM, Cawthraw S, Newell DG (2002) Identification of genetic differences between two Campylobacter jejuni strains with different colonization potentials. Microb 148:1203-1212.

Bauer AW, Kirby WMM, Sherris JC, Turck M (1966) Antibiotic susceptibility testing by standardized single method. Am J Clin Path 45:493-496.

Borsoi A, Santin E, Santos LR, Salle CTP, Moraes HLS, Nascimento VP (2009) Inoculation of newly hatched broiler chicks with two Brazilian isolates of Salmonella Heidelberg strains with different virulence gene profiles, antimicrobial resistence, and pulse field gel electrophoresis patterns to intestinal changes evaluation. Poult Sci 88:750-758.

Bras AM, Chatterjee S, Wren BW, NewellE DG, Ketley JM (1999) A novel Campylobacter jejuni twocomponent regulatory system important for temperature-dependent growth and colonization. J Bacteriol 181:3298-3302.

Chen J, Sun XT, Zeng Z, Yu YY (2011) Campylobacter enteritis in adult patients with acute diarrhea from 2005 to 2009 in Beijing, China. Chin Med J 124:1508-1512.

Deun KV, Pasmans F, Ducateller R, Flahou B, Vissenberg K, Marte A, Broeck V, Immuerssel FV, Haesebrouck F (2008) Colonization strategy of $C$. jejuni results in persistent infection of the chicken gut. Vet Microb 130:285-297.

Fonseca BB, Beletti ME, Melo RT, Mendonca EP, Levenhagem MA, Ueira-Vieira C, Rossi DA (2011) Transfer, viability and colonisation of Campylobacter jejuni in the chicken vitellus and in embryos. Brit Poult Sci 52:279-286.

Guo X, Chen J, Beuchat LR, Brackett RE (2000) PCR detection of Salmonella enteric serotype Montevideo in and on raw tomatoes using primers derived from HilA. Ap Environ Microbiol 5248-5252.

Hänel I, Muller J, Muller W, Schulze E (2004) Correlation between invasion of Caco-2 eukaryotic cells and colonization ability in the chick gut in Campylobacter jejuni. Vet Microb 101:75-82.

Jonker A, Picard JA (1999) Antimicrobial susceptibility in thermophilic Campylobacter species isolated from pigs and chickens in South Africa. J South Afr Vet Assoc 81:228236.

Konkel ME, Kim BJ, Klena JD, Young CR, Ziprin R (1998) Characterization of the Thermal Stress Response of Campylobacter jejuni. Inf Immun 3666-3672.

Konkel ME, Kim BJ, Rivera-Amill V, Garvis SG (1999) Bacterial secreted proteins are required for the internalization of Campylobacter jejuni into cultured mammalian cells. Mol Microbiol 32:691-701

Li YP, Ingmer H, Madsen M, Bang DD (2008) Cytokine responses in primary chicken embryo intestinal cells infected with Campylobacter jejuni strains of human and chicken origin and the expression of bacterial virulence-associated genes. BMC Microbiol 8:107.

Monteville MR, Yoon JE, Konkel ME (2003) Maximal adherence and invasion of INT 407 cells by Campylobacter jejuni re- 
quires the $c a d F$ outermembrane protein and microfilament reorganization. Microbiol 149:153-165.

Pignatari ACC (2011) Epidemiology of Salmonella human infections and the relevance of integrated data in the food products chain. Anais Memorias del Seminario Internacional sobre Salmonellosis Aviar. Rio de Janeiro, 28 a 30 de junio de 2011.

Santos IL, Fonseca BB, Rossi DA, Silva PL, Beletti ME (2011) Alteração da mucosa intestinal de embriões de galinhas provocadas por Campylobacter jejuni In: Conferência FACTA 2011, Santos. Anais da Conferencia Facta 2011.

Yan S, Pendrak M, Foley S, Powers J (2005) Campylobacter infection and GuillainBarré syndrome: public health concerns from a microbial food safety perspective. Clin Appl Imm Rev 5:285-305

Zheng J, Meng JH, Zhao SH, Singh R, Song WX (2006) Adherence to and invasion of human intestinal epithelial cells by Campylobacter jejuni and Campylobacter coli isolates from retail meat products. J Food Prot 69:768-774.

Ziprin RL, Young CR, Byrd JA, Stanker LH, Hume ME, Gray SA, Kim BJ, Konkel ME (2001) Role of C. jejuni potential virulence genes in cecal colonization. Avian Dis 45:549557.

All the content of the journal, except where otherwise noted, is licensed under a Creative Commons License CC BY-NC. 